\title{
Abundance and antibiotic resistance of Aeromonas isolated from the water of three carp ponds
}

\author{
Marta Zdanowicz ${ }^{1} \cdot$ Zbigniew Jan Mudryk $^{1} \cdot$ Piotr Perliński $^{1}$
}

Received: 1 October 2019 / Accepted: 9 January 2020 / Published online: 21 January 2020

(C) The Author(s) 2020

\begin{abstract}
Abundance and antibiotic resistance of bacteria of the genus Aeromonas isolated from the water of three carp ponds were studied. The number of those bacteria differed between the studied ponds, sites and season. The results of the present study showed that planktonic Aeromonas inhabiting those ponds strongly differed in the resistance level to tested antibiotics. These microorganisms were the most resistant to amoxicillin, ampicillin, clindamycin and penicillin. However, all isolates Aeromonas were susceptible to gentamycin and streptomycin. Majority of bacterial strains were characterized by resistance to 4-6 of the 12 antibiotics tested. Bacterial resistance to antibiotics depended on their chemical structure. Aeromonas strains isolated from the studied ponds were the most resistant to $\beta$-lactam and lincosamides antibiotics, while the most susceptible to aminoglycosides, chloramphenicols and fluoroquinolones.
\end{abstract}

Keywords Aeromonas number $\cdot$ Antibiotic resistance $\cdot$ Pond

\section{Introduction}

The genus Aeromonas taxonomically belongs to the class Gammaproteobacteria, order Aeromonadales and the family Aeromonadaceae (Dias et al. 2012). These bacteria are Gramnegative, facultative anaerobic, non-spore forming motile bacilli that inhabit marine and freshwater water basins (Piotrowska and Popowska 2014; Dar et al. 2016). According to Kozińska and Pękala (2010), and Hu et al. (2012) these bacteria are pathogenic to many aquatic animals and are particularly known as important fish opportunistic pathogens. These pathogens are responsible for diseases and mortality of different fish; mainly such species as carp, tilapia, rainbow trout, brown trout, eel, perch, catfish, goldfish and salmon (Hossain et al. 2014). Motile Aeromonas as pathogenic bacteria can kill up to $80-100 \%$ of fish within 12 weeks causing substantial economic losses, due to high mortality rates and worsened quality of produce in fishery farms, mainly for commercial carp farming (Orozova et al. 2010,

Piotr Perliński

piotr.perlinski@apsl.edu.pl

1 Department of Experimental Biology, Institute of Biology and Earth Science, Pomeranian University in Słupsk, Arciszewskiego 22b, 76-200 Słupsk, Poland
Stratev et al. 2015; Mulyani et al. 2018). In particular such species as Aeromonas hydrophila, A.caviae, A.sorbia, A. salmonicida, A. jandei, A.bestiarum and A.veronii are typically associated with diseases and mortality in fish (Beaz-Hidalgo and Figueras 2013; Yu et al. 2015; Chenia 2016). These species are able to synthesize virulence and pathogenicity factors including hemolysins, aerolysin, leukocidin, cytotoxins, enterotoxins, proteases, gelatinase, elastase, lipase, phospholipases, DNase, and adhesin (Das et al. 2013; Yu et al. 2015). Several of these virulence factors have been identified in Aeromonas strains isolated from fish and many water ecosystems (Matyar et al. 2010; Desai and Desai 2014). These factors are the cause of many fish diseases, like external ulcerative lesions, fin rot, ocular ulceration, red sores, reddish head, rotting of the tails, anal region pale body colour, fin haemorrhagic, septicaemia, hemodiapedesis, anorexia, exophalmus and erythrodermatitis, revealed clear ascites, haemorrhage and destruction of sheathed tissues in spleen and renal tubular necrosis in the kidney, liver congestion, enlargement of spleen and kidney and enteritis resulting in major dieoffs and fish kills (Yu et al. 2010; Hu et al. 2012; Rashid et al. 2013).

Several studies (Ozturk et al. 2007; Dias et al. 2012; Yu et al. 2015) suggest that different infections caused by Aeromonas are also closely associated with the change in environmental conditions and such factors as high stocking densities, overcrowding, a sudden change in water and air temperature, rough 
handling, abrasive handling, poor nutritional status, low dissolved oxygen, high levels of carbon dioxide, hypoxia, transfer of fish, mishandling, transportation which often involves traumatic events and stress factors to fish, non-bacterial pathogenic infections, poor water quality - mainly high levels of carbon dioxide and nitrate, organic pollution, and rough weather condition. All these environmental conditions decrease effectiveness of fish immune system which otherwise would clear up bacterial colonization and infection (Cabello 2006; Naylor and Burke 2005).

Intensive fish farming in recent years has resulted in growing problems of bacterial diseases, which led to a widespread antibiotic use for their treatment (Guz and Kozinska 2004; Daood 2012). Wide use of antibiotics to prevent and treat bacterial diseases and the application of subtherapeutic dose of antibiotics have inducted a global increase in the levels of antibiotic resistance among pathogenic bacteria in fish farming (Patil et al. 2016; Mulyani et al. 2018). As a result, the development of antibiotic resistance among aquatic bacterial pathogens will ultimately reduce the efficiency of antimicrobial agents used for treating and can favour the development of resistant bacteria in native fish species (Belèm-Costa and Cyrino 2006). Moreover, the increased antibiotic resistance confers bacterial pathogens an additional virulent feature, which generates increased mortality of fish in commercial farms (Daood 2012).

According to Dias et al. (2012) and Patil et al. (2016) Aeromonas strains are known as good indicator bacteria suitable for studying the incidence and development of antibiotic resistance in fish farms. Therefore, the aim of this study was to determine the number and investigate antibiotic resistance profiles among Aeromonas strains isolated from the water of carp (Carpinus carpio) three ponds.

\section{Material and methods}

\section{Study area and sampling}

This study was carried out in three carp ponds, fry, fingerling and adult located in Wiklino (North Poland); their characteristics was given in Table 1. A common feature of all these ponds is the cycle of filling and emptying the reservoirs with river water during the period of its excess or deficit used in traditional carp farming. Fish in the studied fish farm were adequately fed with the commercial pelleted feed.

Water samples were collected from each pond at three sites (Fig. 1) in the spring, summer and autumn seasons in 2013:

Site 1 - located in the zone near the water inflow, Site 2 - located in the central part of the pond, Site 3 - located in the zone near the water outflow.
Table 1 Values of selected morphometry and some physicochemical parameters of studied ponds.

\begin{tabular}{lllll}
\hline Parameters & & Fry pond & Fignerling pond & Adult pond \\
\hline Pond type & & artificial & artificial & natural \\
Area & & $0.5 \mathrm{ha}$ & $3 \mathrm{ha}$ & $3 \mathrm{ha}$ \\
Average depth & & $0.7 \mathrm{~m}$ & $0.8 \mathrm{~m}$ & $0.9 \mathrm{~m}$ \\
Temperature & spring & 17.2 & 17.3 & 16.8 \\
& summer & 22.0 & 22.7 & 20.3 \\
& autumn & 9.3 & 9.7 & 8.7 \\
$\mathrm{pH}$ & spring & 7.2 & 7.7 & 7.7 \\
& summer & 7.8 & 7.5 & 7.8 \\
& autumn & 7.8 & 7.7 & 7.8 \\
\hline
\end{tabular}

Water samples were collected from the depth of about $15 \mathrm{~cm}$ below the water surface directly into sterile glass bottles. Collected water samples were stored in an ice - box, where the temperature did not exceed $+7{ }^{\circ} \mathrm{C}$, and immediately transported to the laboratory. Microbiological assays as a rule were conducted within 4-6 $\mathrm{h}$ from the time of the sample collection.

\section{Determination of the abundance of Aeromonas bacteria}

According to the procedures described by Mudryk et al. (2015) in order to determine Aeromonas abundance in the collected samples of water, these samples were diluted with sterile phosphate - buffered saline to reach final concentration ranging from $10^{-1}$ to $10^{-3}$. Diluted water samples were filtered through a $0.45-\mu \mathrm{m}$ pore size, $47 \mathrm{~mm}$ - diameter membrane filters (Whatman ME 25/31 ST). The filters were then aseptically transferred to the plates containing $10 \mathrm{ml}$ of Aeromonas Isolation Agar (Biocorp) with ampicillin as a selective agent to reduce the growth of non-aeromonads (Jenkins and Taylor 1995). The plates were incubated at $37^{\circ} \mathrm{C}$ for $48 \mathrm{~h}$ in portable incubator. After incubation, the plates presenting dark green, opaque with darker center colonies were determined according to Clark et al. (2003) as presumptive Aeromonas.. Number of Aeromonas was counted and results were calculated as colony forming units (CFU) per $1 \mathrm{ml}$ of water. All presumptive Aeromonas bacterial isolates were than subject to various characterizations which eventually led to their identification. A series of morphological (shape, size, Gram character, flagellation) and conventional biochemical tests were performed to characterize the suspected Aeromonas. All strains which were Gram negative rods, positive for such enzymes as cytochrome oxidase, catalase and DNase, oxidative-fermentative $(\mathrm{OF})$, acid and gas production from sugars (glucose, lactose, maltose, sucrose and manitol), methyl-red, $\mathrm{H}_{2} \mathrm{~S}$ production, 
Fig. 1 Map studied ponds where the sampling sites are located

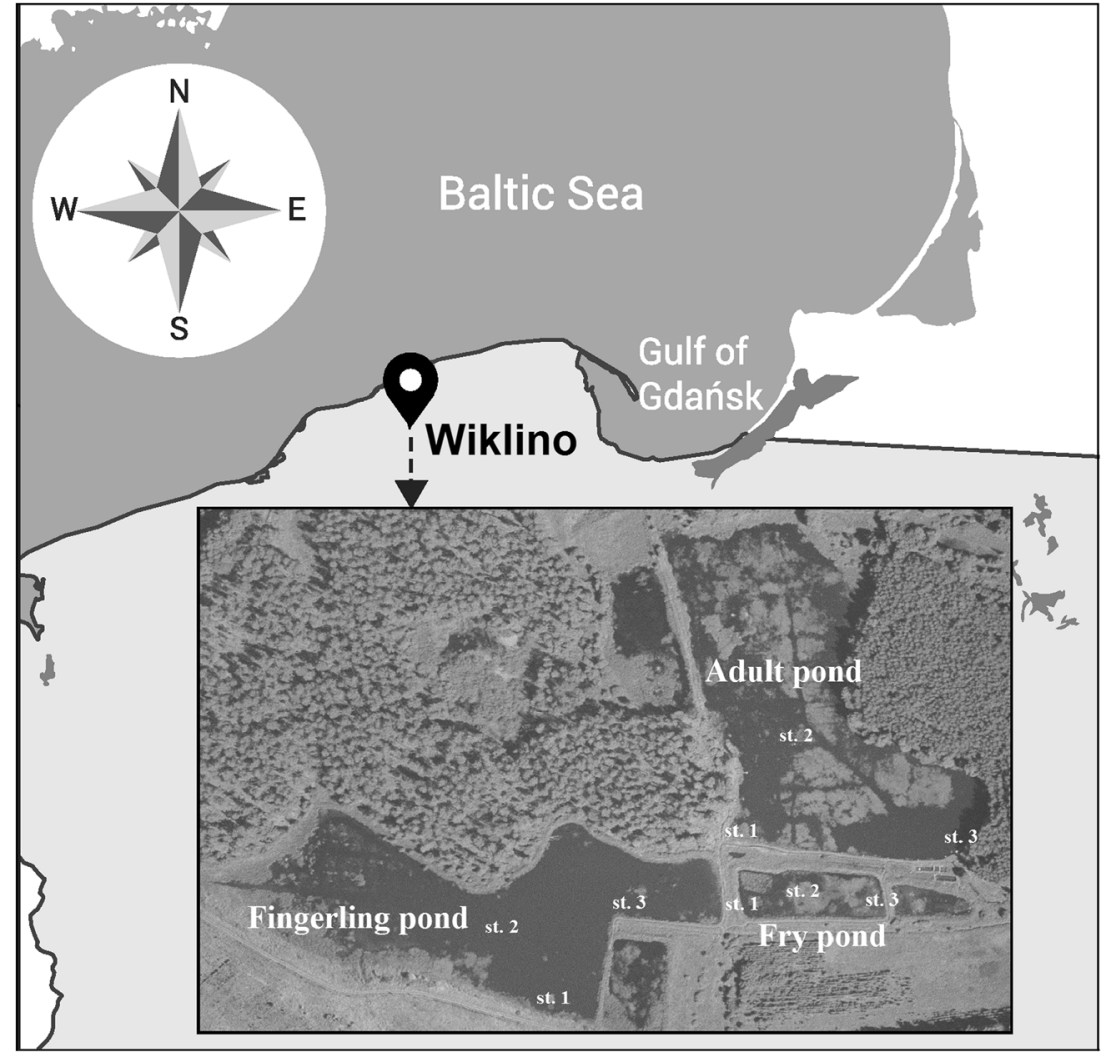

were according to Jeeva et al. (2013) and Rashid et al. (2013) identified as Aeromonas.

\section{Antibiotic resistance profiling of Aeromonas spp. isolates}

A total of 106 Aeromonas spp. isolates were determined based on their profiles of antibiotic resistance according to the single disc diffusion method described in details by Mudryk et al. (2015). In order to determine antibiotic resistance, bacteria were multiplied on Mueller - Hinton (M - H) (Oxoid) agar slants at $20^{\circ} \mathrm{C}$ for $24 \mathrm{~h}$. Multiplied bacteria were washed off with $5 \mathrm{ml}$ of sterile phosphate - buffered saline and the optical density culture was adjusted to 2.5 MacFarland standard units. Subsequently, $0.2 \mathrm{ml}$ of bacterial suspension prepared in this way was introduced into dissolved $\mathrm{M}-\mathrm{H}$ agar cooled to 40 $45^{\circ} \mathrm{C}$. After mixing, the sample was poured onto Petri dishes and dried in a drier at $37^{\circ} \mathrm{C}$ for $1 \mathrm{~h}$. Paper discs impregnated with an antibiotic were then applied to the surface of the seeded medium with an automatic disk dispenser at distances no less than $2 \mathrm{~cm}$. The blotting paper discs $(\varphi 13 \mathrm{~mm})$ were manufactured by Oxoid Company. The dishes were kept at $4{ }^{\circ} \mathrm{C}$ for $1 \mathrm{~h}$ in order to allow antibiotic diffusion from the discs into the agar medium and then incubated at $20^{\circ} \mathrm{C}$ for $24 \mathrm{~h}$. The degree of resistance or sensitivity of the strains was determined on the basis of the measurements of lightened zones (in $\mathrm{mm}$ ) around the disc and comparing them with the data given by the manufacturer instructions. The strains showing resistant or intermediate behaviour were subsumed under the category resistant. All others strains were classified as sensitive. The following twelve antibiotics (their codes and concentrations $[\mu \mathrm{g}$ disc] were given in parentheses), which are commonly used in clinical practice and in aquaculture were tested in antibiograms: amoxicillin (AX $25 \mu \mathrm{g}$ ), ampicillin (AM $10 \mu \mathrm{g}$ ), chloramphenicol (C $30 \mu \mathrm{g}$ ), ciprofloxacin (CIP $5 \mu \mathrm{g}$ ), clindamycin (CA $2 \mu \mathrm{g}$ ), erythromycin (E $15 \mu \mathrm{g}$ ), gentamycin (GN $10 \mu \mathrm{g})$, neomycin (N $30 \mu \mathrm{g})$, oxytetracycline (OT $30 \mu \mathrm{g}$ ), penicillin (P $10 \mu \mathrm{g}$ ), streptomycin (S $300 \mu \mathrm{g}$ ) and tetracycline (TE $30 \mu \mathrm{g}$ ) manufactured by Oxoid Company. The results were used to calculate the Antibiotic Resistance Index (ARI = no. of antibiotics to which the isolate was resistant / total no. of antibiotics tested) (Webster et al. 2004). The strain Aeromonas hydrophila ATCC 7966 was used as control for verification of the anti-bacterial effect of the disc on Muller-Hinton agar plates (Yucel et al. 2005).

All tested antibiotics according to their chemical structure were divided into seven groups: aminoglycosides (AMG) (gentamycin, neomycin, streptomycin), $\beta$-lactams (LA) (amoxicillin, ampicillin, penicillin), chloramphenicols (CHL) (chloramphenicol), lincosamides (LIN) (clindamycin), macrolides (MAC) (erythromycin), fluoroquinolones (FLU) (ciprofloxacin) and tetracyclines (TET) (tetracycline, 
oxytetracycline) (Reinthaler et al. 2003). Isolated Aeromonas strains were also analyzed for the multiple antibiotic resistance (MAR) according to Mudryk et al. (2015).

\section{Statistic analyses}

Statistical tests (standard deviation-SD, coefficient of variation-CV, coefficient of dispersion-CD) used in this analysis were based on Velji and Albright (1986). Relationships among parameters within the whole data set were examined using Spearman's rank correlation coefficient using Statistica software. The significance of differences between ponds, seasons and sites in level of number of Aeromonas was assessed using Kruskal - Wallis non-parametric equivalent of ANOVA, when mean values revealed a distribution other than normal.

\section{Results}

The data on the abundance of bacteria representing the genus Aeromonas in water samples collected at the study sites of three carp ponds were given in Table 2. According to these data, Aeromonas were the most abundant in fingerling pond (mean: $2.96 \cdot 10^{2} \mathrm{CFU} / \mathrm{ml}$ ), while their number was the lowest in adult pond $\left(1.93 \cdot 10^{2} \mathrm{CFU} / \mathrm{ml}\right)$. The highest average number of these bacteria $\left(3.11 \cdot 10^{2} \mathrm{CFU} / \mathrm{ml}\right)$ was isolated from water samples collected in the zone near the water outflow (st.3) from the studied ponds, while the lowest $\left(2.22 \cdot 10^{2} \mathrm{CFU} / \mathrm{ml}\right)$ was recorded in the zone near the water inflow (st.1). In fry pond, Aeromonas bacteria were the most abundant at the sites 1 and $3\left(2.89 \cdot 10^{2} \mathrm{CFU} / \mathrm{ml}\right)$ and their number was the lowest $\left(2.22 \cdot 10^{2} \mathrm{CFU} / \mathrm{ml}\right)$ in the central part of the pond (st.2). In fingerling pond, the maximum number of bacteria of the genus Aeromonas was noted at the site $3\left(4.22 \cdot 10^{2} \mathrm{CFU} / \mathrm{ml}\right)$

Table 2 Occurrence and abundance of Aeromonas in water samples collected from studied carp ponds (data derived from the pooled data of all seasons)

\begin{tabular}{lllllll}
\hline Pond & Site & CFU $(\mathrm{ml})$ & Range & SD & CV(\%) & CD \\
\hline fry & st. 1 & 289 & $0-733$ & 390 & 135.0 & 526.5 \\
& st. 2 & 222 & $0-600$ & 329 & 148.1 & 487.1 \\
& st. 3 & 289 & $200-400$ & 102 & 35.3 & 36.0 \\
& average & 267 & & & & \\
fingerling & st. 1 & 178 & $133-267$ & 76 & 42.8 & 32.5 \\
& st. 2 & 289 & $67-533$ & 234 & 81.0 & 189.5 \\
& st. 3 & 422 & $200-667$ & 234 & 55.4 & 129.7 \\
& average & 296 & & & & \\
adult & st. 1 & 200 & $67-400$ & 176 & 88.0 & 154.9 \\
& st. 2 & 156 & $0-467$ & 269 & 172.9 & 465.2 \\
& st. 3 & 222 & $0-533$ & 278 & 125.1 & 347.8 \\
& average & 193 & & & & \\
\hline
\end{tabular}

located near the water outflow from the pond, while the minimum $\left(1.78 \cdot 10^{2} \mathrm{CFU} / \mathrm{ml}\right)$ at the site 1 near the water inflow. The maximum number of bacteria of the Aeromonas in adult pond was recorded at the site $3\left(2.22 \cdot 10^{2} \mathrm{CFU} / \mathrm{ml}\right)$ and the minimum $\left(1.56 \cdot 10^{2} \mathrm{CFU} / \mathrm{ml}\right)$ at the site 2 .

The number of Aeromonas bacteria inhabiting studied carp ponds showed clear seasonal dynamics (Fig. 2). The highest average number of Aeromonas $\left(3.03 \cdot 10^{2} \mathrm{CFU} / \mathrm{ml}\right)$ was recorded in the studied ponds in summer and the lowest $(2.00$. $10^{2} \mathrm{CFU} / \mathrm{ml}$ ) during the autumn season. The maximum number of the studied bacterial group was noted in fry pond in spring, while during summer these bacteria were the most abundant in adult pond, and in the autumn season - in fingerling pond.

The data presented in Table 3 showed that Aeromonas isolates significantly differed in the level of resistance to twelve studied antibiotics commonly used in human medicine, veterinary and aquaculture. In all studied ponds the highest (9699\%) average percentage of all tested Aeromonas strains was resistant to amoxicillin, ampicillin, clindamycin and penicillin. About $60 \%$ of isolates was also resistant to erythromycin. On the other hand only 5-6\% of tested strains were resistant to chloramphenicol and ciprofloxacin. However, all Aeromonas isolates were susceptible to gentamycin and streptomycin. The Antibiotic Resistance Index (ARI $=0.4-0.5$ ) of planktonic Aeromonas. indicated that there was no difference in the level of antibiotic resistance between the studied fish ponds.

Isolated Aeromonas strains were also analysed for the multiple antibiotic resistance (MAR) (Fig. 3). From 17 up to 39\% of planktonic Aeromonas strains showed resistance against four to six antibiotics and about $8-10 \%$ of tested strains were resistant to seven and eight antibiotics out of the twelve analysed drugs. None of bacteria inhabiting the studied ponds was found to be resistant to 1-3 and 11-12 of tested antibiotics.

The resistance level of Aeromonas to different classes of antibiotics is shown in Fig. 4. The results of present study showed that bacterial resistance depended on antibiotics' chemical structure. Aeromonas isolated from the studied ponds were the most resistant to $\beta$ - lactams and to lincosamides antibiotics. On other hand, isolated strains were the most susceptible to aminoglycosides, chloramphenicols and fluoroquinolones.

The relationships abundance of Aeromonas in studied fish ponds are given as the correlation matrix in Table 4. In water studied water basins noted positive $(\mathrm{r}=0.82, p<0.05)$ correlations between site 2 and site 3 and negative $(r=-081, p<$ 0.05 ) correlations between summer and spring.

By grouping the results by the ponds, seasons and sites Kruskal-Wallis test carried out to detect significant differences between the number of Aeromonas bacteria (Table 5). The number of Aeromonas non-significant differences between studied parameters were noted. Only significance difference $(\mathrm{H}=$ $18.947, p<0.05)$ between ponds and seasons were observed. 
Fig. 2 Seasonal dynamics change of Aeromonas bacteria number in water studied ponds (average from the pooled data of all sites and seasons)

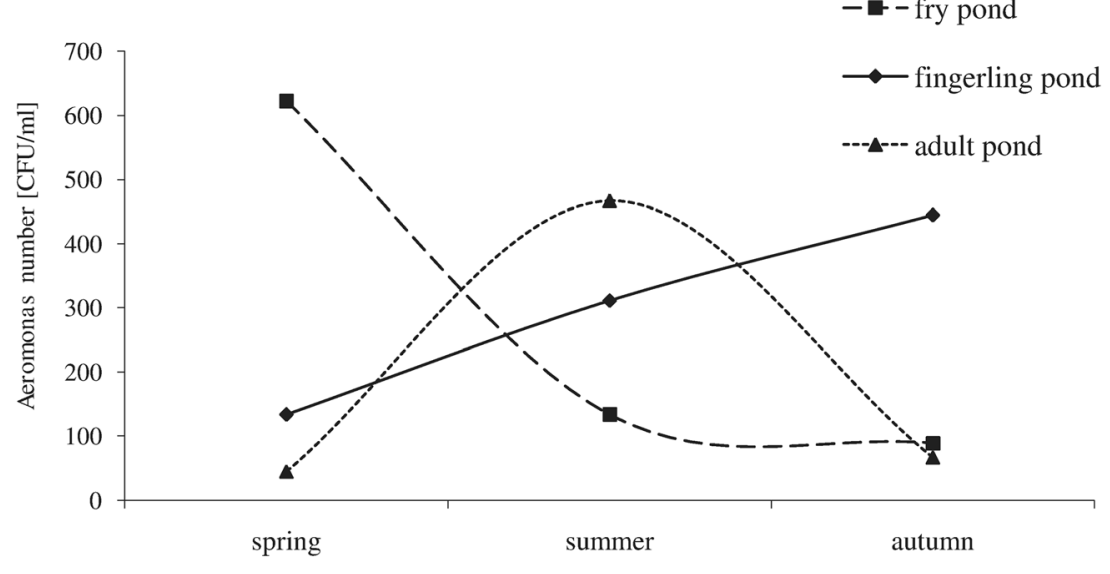

\section{Discussion}

The genus Aeromonas along with Pseudomonas and Vibrio are the predominant microorganisms in ponds and these bacteria may be used as good biological indicators of water quality (Rippey and Cabelli 1989; Korzekwa et al. 2012). The number of Aeromonas bacteria inhabiting the water of three studied carp ponds varied from 1.93 to $2.96 \cdot 10^{2} \mathrm{CFU} / \mathrm{ml}$. This level number of Aeromonas was similar $\left(2.4 \cdot 10^{2} \mathrm{CFU} / \mathrm{ml}\right)$ to data reported by Leung et al. (1992) from aquaculture ponds at Aburn University and local fish farm in India $\left(3.63 \cdot 10^{2} \mathrm{CFU} /\right.$ $\mathrm{ml}$ ) (Jha et al. 2008) but lower than the values noted by Gołas et al. (2019) in aquaculture system farming of European grayling $\left(11.0 \cdot 10^{3} \mathrm{CFU} / \mathrm{ml}\right)$ and the number of Aeromonas (2.1-

Table 3 Percentage of antibiotic resistance among Aeromonas isolated from water of three studied ponds

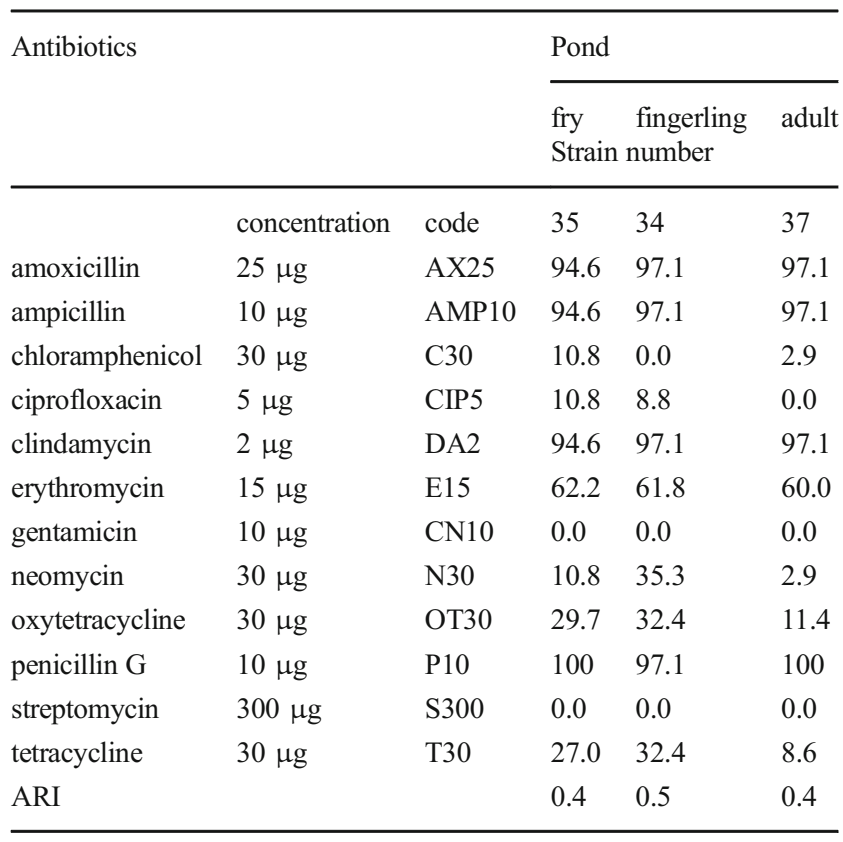

2.6 $10^{6} \mathrm{CFU} / \mathrm{ml}$ ) in river water of Lotcha (West Bengal,India) (Roy et al. 2013).

According to the obtained results, the number of Aeromonas bacteria inhabiting the studied ponds showed clear seasonal dynamics, which is consistent with the studies of Topić Popović et al. (2000) and Maalej et al. (2003). The maximum number of Aeromonas was recorded in the studied ponds in summer and the minimum in autumn. Summer maxima in the number of that taxonomic group may be the effect of relatively high temperatures at this time of year (Mudryk and Skórczewski 2007; Zdanowicz and Mudryk 2017). According to Cottrell and Kirchman (2000) temperature is a major abiotic factor influencing significantly the seasonal variation in the abundance of bacteria in aquatic ecosystems.

In recent years the number of antibiotic-resistant bacteria in aquaculture has increased dramatically in different parts of the world (Orozova et al. 2008). It is a consequence of the widespread and often uncontrolled use of antibiotics, prophylactically and therapeutically, against diseases, and also subtherapeutically as growth promoters for aquatic farm animals, mainly fish (Ozturk et al. 2007; Ramesh et al. 2010).

In the present study we showed that Aeromonas strains isolated from the water of three carp ponds were characterised by large differences in their resistance to particular antibiotics. Among all isolated strains the highest percentage (96-99\%) was resistant to amoxicillin, ampicillin, clindamycin and penicillin. Significant percentage (70-100\%) of Aeromonas strains showed resistance to $\beta$-lactam antibiotics, like amoxicillin, ampicillin and penicillin and similar results were reported by many researchers, for example, Yu et al. (2015) from the carp farm in Korea, Guz and Kozinska (2004) and Harnisz and Tucholski (2010) from carp ponds in Poland, and Yano et al. (2015) from inland ponds located in Bangkok (Thailand). According to Saavedra et al. (2004) the genus Aeromonas is considered naturally resistant to $\beta$ - lactam antibiotics. Due to chemically unstable $\beta$ - lactam ring in structure of $\beta$ - lactam antibiotics, they are readily susceptible to bacterial hydrolysis by chromosomal $\beta$ - lactamases produced 
Fig. 3 Percentage of resistance to 12 antibiotics of the Aeromonas strains isolated from three farmed carp ponds (data derived from the pooled data of all sites during the study period)

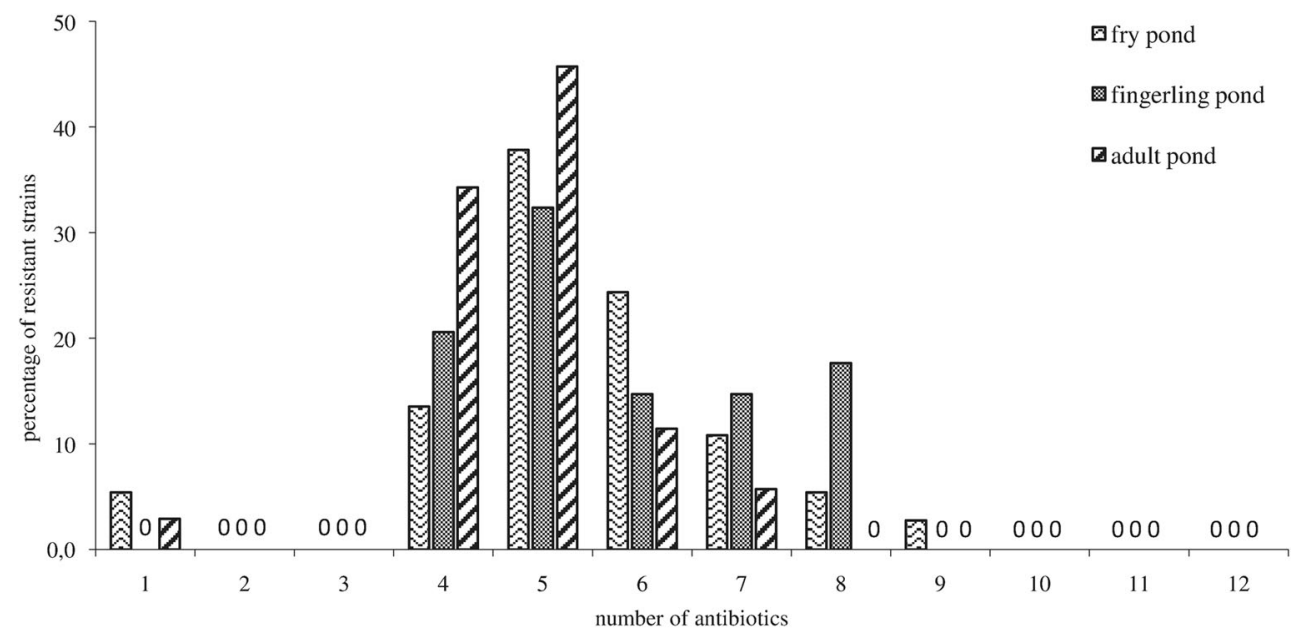

by Aeromonas and are easily eliminated (Goňi-Urriza et al. 2000). In the present study, the high level of antibiotic resistance against amoxicillin, ampicillin and penicillin shown by many Aeromonas strains isolated from the water of the studied ponds indicated that the $\beta$ - lactamase gene might be widely present in the gene pool of microbes in the studied aquatic environment (Lin et al. 2004).

In our study, Aeromonas strains inhabiting the water of three carp ponds were also characterized by high (96\%) resistance to clindamycin. These results are comparable with the data obtained by Stratev et al. (2015) who noted that all Aeromonas strains isolated from rainbow trout were resistant to clindamycin and similar results reported also Mudryk et al. (2015) from marine water.

On the other hand, relatively low percentage (5-6\%) of Aeromonas inhabiting the studied carp ponds showed resistance to ciprofloxacin and chloramphenicol. Similarly, only 0-10\% of Aeromonas strains isolated by Hatha et al. (2005) in the farm of freshwater fish in India, Vivekanandhan et al.
(2002) in fish collected from fish market (South India), Yano et al. (2015) in inland ponds located in Bangkok city were resistance to ciprofloxacin and chloramphenicol. According to Roberts (1993) chloramphenicol as well as ciprofloxacin are often used prophylactically in fish farms.

In the present study we observed that none of the isolated strains showed resistance to streptomycin and gentamycin. Our results on the sensitivity of Aeromonas strains to streptomycin and gentamycin are consistent with the results obtained by Radu et al. (2003) in seven fish farms of Merisian province (Turkey), Belèm-Costa and Cyrino (2006) from tilapia and pacu and Kanchan et al. (2016) from fish collected from local farm culture Kosumpisi District Maha Sarakham Province (Thailand) who showed that $100 \%$ of this taxonomic group of bacteria was susceptible to both antibiotics.

The present study showed multiple antibiotic resistance of planktonic Aeromonas strains inhabiting the studied ponds. The majority of these bacteria were resistant against four to six antibiotics of the twelve antibiotics used in this study. This
Fig. 4 The resistance of studied bacteria with respect to their chemical structure (in percentage) (percentages derived from the pooled data of all sites and seasons)

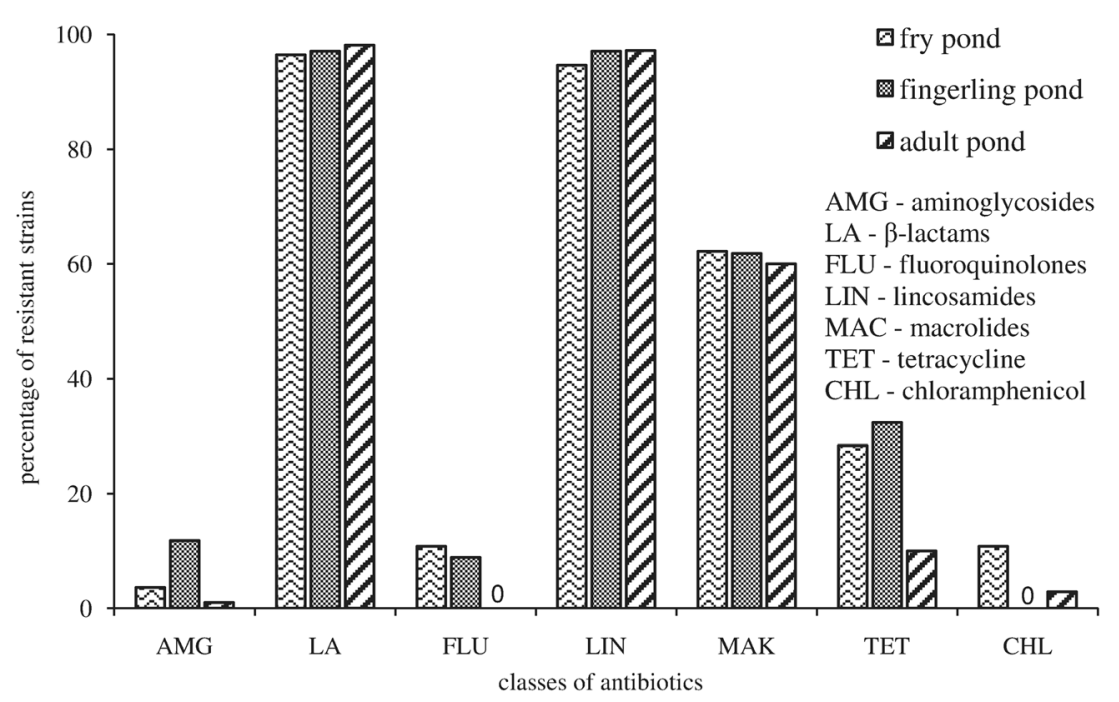


Table 4 Correlation matrix coefficient numbers of Aeromonas in the water fish ponds

\begin{tabular}{lllll}
\multicolumn{4}{l}{ Nonparametric Spearman's correlation coefficients } & \\
\hline \multirow{4}{*}{ ponds } & fry & fingerling & adult \\
& fingerling & -0.36 & & \\
& adult & -0.21 & 0.33 & \\
& & spring & summer & autumn \\
\multirow{4}{*}{ seasons } & spring & & & \\
& summer & $-0.81^{* *}$ & & \\
& autumn & -0.10 & 0.08 & \\
& & 1 & 2 & \\
sites & 1 & & & \\
& 2 & 0.65 & $0.82 * *$ & \\
\hline
\end{tabular}

Significance $(\mathrm{p})$ is indicated by asterisks: $* * p<0.01$.

means that they are capable of detoxification of those antibacterial organic compounds and indicates that most Aeromonas strains inhabiting the studied ponds originate from the highrisk sources of contamination, where antibiotics are often used (Orozova et al. 2008). Adaptive responses of bacterial communities to several antibiotics observed in the present study may have possible implications for the health of animals raised in the studied aquacultures (Rhodes et al. 2000; Orozova et al. 2008) and may reflect the history of antibiotic application (Hsu et al. 1992). Multiple antibiotic resistance in Aeromonas species inhabiting different water basins have been reported globally by many authors (Matyar et al. 2010; Yano et al. 2015; Deng et al. 2016). For this reason according to John and Hatha (2012) the development of multiple antibiotic resistance by different Aeromonas species, mainly such as Aeromonas hydrophila, A. veronni, A.salmonicida, A.sorbia and A.caviae, isolated from aquaculture environments

Table 5 Analyses of the Kruskal - Wallis test in the numbers of Aeromonas in the water due to fish ponds, seasons and sites. Significance ( $p$ ) is indicated by asterisks: $* \mathrm{p}<0.05$

\begin{tabular}{lll}
\hline Source of variation & $\mathrm{H}$ & $\mathrm{p}$ \\
\hline ponds & 1.703 & $\mathrm{~ns}$ \\
seasons & 1.830 & $\mathrm{~ns}$ \\
sites & 1.536 & $\mathrm{~ns}$ \\
ponds $\times$ seasons & 18.947 & $*$ \\
ponds $\times$ sites & 4.180 & $\mathrm{~ns}$ \\
seasons $\times$ sites & 5.918 & $\mathrm{~ns}$ \\
\hline
\end{tabular}

Explanations:

$\mathrm{H}$ - the Kruskal - Wallis test

$\mathrm{p}$ - significance level

ns - non-significant
(Igbinosa et al. 2012) in recent years has become a major problem in many parts of the world. The rapid increase in the number of resistant and multiresistant aquatic genus Aeromonas is due to the ability of these organisms to transfer antibiotic resistance by mobile genetic agents (plasmids, transposons, IS elements, gene cassettes, class 1 integrons) among bacterial populations by cell to cell contact (Dar et al. 2016; Patil et al. 2016; Piotrowska et al. 2017). Many of those mobile elements harbor multiple antimicrobial resistance determinants resulting in the propagation of antibiotic resistance in aquaculture environments (Patil et al. 2016).

Most classes of antibiotics that are used in medicine and veterinary are introduced into water basins (Ko et al. 2003; Lin et al. 2004). According to Reinthaler et al. (2003) and Mudryk (2005) bacterial resistance to antibiotics depends on their chemical structure. The occurrence of antibiotic resistance genes against different groups of antibiotics in the genus Aeromonas derived from aquacultures is widely known (Jacobs and Chenia 2007; McIntosh et al. 2008; Piotrowska and Popowska 2014); this is also confirmed by the results of the present study. Aeromonas strains isolated from the water of three studied ponds were the most resistant to $\beta$ - lactam antibiotics. This class of antibiotics is the most widely used (approximately $50 \%$ of global antibiotic consumption) because they have low toxicity and are used to treat a broad range of infections (Livrmore 1996). $\beta$ - lactam antibiotics inhibit the activity of enzymes participating in the biosynthesis of the bacterial cell wall by interrupting the trans peptidation process that links the peptidoglycan components of the bacterial wall to each other (Roberts 1998). The resistance of Aeromonas to $\beta$ - lactam antibiotics is due to their ability to synthesize three extracellular enzymes: $\beta$ lactamase, acylase and penicillinase, which hydrolyse the amide bond of the $\beta$ - lactam ring of $\beta$ - lactam antibiotics and can also limit the permeability of cytoplasmic membranes to those antibiotics (Guz and Kozinska 2004; Saavedra et al. 2004). Thanks to the ability for the synthesis of these enzymes Aeromonas strains are capable of detoxifying those antimicrobial agents. The number of Aeromonas strains producing an extended spectrum of $\beta$-lactamases capable of hydrolysing $\beta$ - lactam antibiotics is increasing, therefore resistance to $\beta$ lactams may become a serious problem all over the world (Schwartz et al. 2003).

Apart from $\beta$ - lactam antibiotics, 96\% Aeromonas strains isolated from the water of the studied ponds were resistant to lincosamide antibiotics. Lincosamides are one of the commonly used antibiotic classes in human and veterinary clinical practice, which occur in many water ecosystems (Andreozzi et al. 2006). High resistance of the studied taxonomic group of bacteria to these antibiotics is because lincosamides efficiently inhibit growth in Gram-positive bacteria, mainly staphylococcal and streptococcal forms, but have low activity against many Gram-negative bacteria, such as Aeromonas bacteria 
(Lüthje and Schwarz 2007). Resistance of Aeromonas strains isolated from the studied ponds to this class of antibiotics corresponds with the studies carried out in other water basins (Calamari et al. 2003; Andreozzi et al. 2006). According to Lüthje and Schwarz (2007) bacterial resistance to lincosamide antibiotics can be due to target site modification, active efflux mechanisms, mutations and enzymatic inactivation on the drugs. Our results also indicated that Aeromonas strains were able to follow at least one of the resistance mechanisms mentioned above, since such a high percentage of those organisms were resistant to lincosamide antibiotics.

Several studies (Ko et al. 2003; Orozova et al. 2008; Yu et al. 2015) reported that Aeromonas isolates are susceptible in vitro to aminoglycoside antibiotics. Also Aeromonas strains isolated from the water of the studied ponds apart from chloramphenicols and fluoroquinolones were the most susceptible to aminoglycoside antibiotics. This means that the studied genus of bacteria is not capable of actively detoxifying those antimicrobial agents. Aminoglycosides are a large and diverse class of antibiotics, which have bactericidal activity against some Gram - positive and many Gram - negative organisms (Ryu and Rando 2001). Aminoglycoside inhibition of bacterial cell growth occurs by inhibition of one or more of the biochemical steps involved in translation on the ribosome and disrupts the integrity of the bacterial cell membrane (Wright 2003).

\section{Conclusions}

In conclusion, we pointed out that antibiotic resistance and multiple resistance to antibiotics of Aeromonas genus inhabiting the water of carp ponds still require explanation and prompt the need to evaluate their potential role in fish infections, in which antibiotic therapy would be required. Further studies are essential for better understanding of antibiotic resistance of Aeromonas in aquacultures particularly, where uncontrolled and extensive use of antibiotics may cause the frequent occurrence of multiple antibiotics resistance. The resistance of bacteria to antibiotics could be an important problem in the future, not only in fish health but also in public health as a result of the possible transmission of the antibiotic resistance to humans by fish carriers' consumption.

Acknowledgements The authors are thankful to the Miss Karolinia Ignasiak for her contribution in performing the bacteriological analysis.

Open Access This article is licensed under a Creative Commons Attribution 4.0 International License, which permits use, sharing, adaptation, distribution and reproduction in any medium or format, as long as you give appropriate credit to the original author(s) and the source, provide a link to the Creative Commons licence, and indicate if changes were made. The images or other third party material in this article are included in the article's Creative Commons licence, unless indicated otherwise in a credit line to the material. If material is not included in the article's Creative Commons licence and your intended use is not permitted by statutory regulation or exceeds the permitted use, you will need to obtain permission directly from the copyright holder. To view a copy of this licence, visit http://creativecommons.org/licenses/by/4.0/.

\section{References}

Andreozzi R, Carerino M, Lo Giudice R, Marotta R, Pinto G, Pollio A (2006) Lincomycin solar photodegradation, algal toxicity and removal from wastewaters by means of ozonation. Water Res 40: 630-638

Beaz-Hidalgo R, Figueras MJ (2013) Aeromonas spp. whole genomes and virulence factors implicated in fish disease. J Fish Dis 36:371388

Belèm-Costa AB, Cyrino JE (2006) Antibiotic resistance of Aeromonas hydrophila isolated from Piaractus mesopotamicus (Holmberg 1887) and Oreochromis niloticus (Linnaeus, 1758). Sci Agric 63: 281-284

Cabello FC (2006) Use of prophylactic antibiotics in aquaculture a growing problem for human abd animal health for the environment. Environ Microbial 8:1137-1144

Calamari D, Zuccato E, Castiglioni S, Bagnati R, Fanelli R (2003) Strategic survey of therapeutic drugs in the rives Po and Lambro in northern Italy. Environ Sci Technol 37:1241-1248

Chenia HY (2016) Prevalence and characterization of plasmid-mediated quinolone resistance genes in Aeromonas spp. isolated from south African freshwater fish. Int J Food Microbiol 231:26-32

Clark AT, Tuner K, Dorothy P, Goutham J, Klavati C, Rajanna B (2003) Health hazards due to pollution of waters along the coast of Visakhapatnam, east coast of India. Ecotox Environ Safe 56:390 397

Cottrell MT, Kirchman DL (2000) Community composition of marine bacterioplankton determined by 16S rRNA gene clone libraries and fluorescence in situ hybridization. Appl Environ Microbiol 66: $5116-5122$

Daood N (2012) Isolation and antibiotic susceptibility of Aeromonas spp. from freshwater fish farm and farmed carp (dam of 16 Tishreen, Lattakia). Damascus Univ J Basic Sci 28:27-39

Dar GH, Kamili AN, Chishti MZ, Dar SA, Tantry TA, Ahmad F (2016) Characterization of Aeromonas sobria isolated from fish Rohu (Labeo rohita) collected from polluted pond. J Bacteriol Parasitol 7. https://doi.org/10.4172/2155-9597.1000273

Das A, Rathore A, Janani C, Hemanth C, Balakrishnan RA (2013) Diagnosis of motile Aeromonas sobria from catfish with septicemia by PCR. J Agri Vet Sci 2:87-91

Deng Y, Wu Y, Jiang L, Tan A, Zhang R, Luo L (2016) Multi-drug resistance mediated by class 1 integrons in Aeromonas isolated from farmed freshwater animals. Front Microbiol 7. https://doi.org/10. 3389/fmicb2016.00935

Desai B, Desai P (2014) Biofilm formation and effect of disinfectants on the isolated obtained from aquatic ecosystems. Biomed Res J 1:1-7

Dias C, Mota V, Martinez-Murcia A, José Saavedra M (2012) Antimicrobial resistance patterns of Aeromonas spp. isolated from ornamental fish. J Aquacult Res Dev:3. https://doi.org/10.4172/ 2155-9546.1000131

Gołaś I, Szmyt M, Potorski J, Łopata M, Gotkowska-Płachta A, GlińskaLewczuk K (2019) Distribution of Pseudomonas fluorescens and Aeromonas hydrophila bacteria in a recirculating aquaculture system during farming of european grayling (Thymallus thymallus L.) Broodstock. Water 11:376. https://doi.org/10.3390/w11020376

Goňi-Urriza U, Capdepuy MC, Arpin C, Raymond N, Caumette P, Quentin C (2000) Impact of an urban effluent on antibiotic 
resistance of riverine Enterobacteriaceae and Aeromonas spp. Appl Environ Microbiol 66:125-132

Guz L, Kozinska A (2004) Antibiotic susceptibility of Aeromonas hydrophila and A. sobria isolated from farmed carp (Cyprinus carpio L.). Bull Vet Inst Pulawy 48:391-395

Harnisz M, Tucholski S (2010) Microbial quality of common carp and pikeperch fingerlings cultured in a pond fed with treated wastewater. Ecol Eng 36:466-470

Hatha M, Vivekanandhan AA, Joice GJ, Christol (2005) Antibiotic resistance pattern of motile aeromonads from farm raised fresh water fish. Int J Food Microbiol 98:131-134

Hatha JN (2012) Prevalence, distribution and drug resistance of motile aeromonads in freshwater ornamental fishes. Indian J Fish 59:161164

Hossain MJ, Sun D, McGarey DJ, Wrenn S, Alexander LM, Martino ME, Xing Y, Terhune JS, Liles MR (2014) An Asian origin of virulent Aeromonas hydrophila responsible for disease epidemics in United States-farmed catfish. mBio 5:e00848-e00814. https://doi.org/10. 1128/mBio.00848-14

Hsu CH, Hwang SC, Liu JK (1992) Succession of bacterial drug resistance as an indicator of antibiotic application in aquaculture. J Fish Soc Taiwan 19:55-64

Hu M, Wang N, Pan ZH, Lu CP, Liu YJ (2012) Identity and virulence properties of Aeromonas isolates from diseased fish, healthy controls and water environment in China. Lett Appl Microbiol 55:224 223

Igbinosa IH, Igumbor EU, Aghdasi F, Tom M, Okoh AI (2012) Emerging Aeromonas species infections and their significance in public health. Sci World J. https://doi.org/10.1100/2012/625023

Jacobs L, Chenia HY (2007) Characterization of integrons and tetracycline resistance determinants in Aeromonas spp. isolated from south African aquaculture systems. Int J Food Microbiol 114:295-306

Jeeva S, Packia Lekshmi NCJ, Raja Brindha J, Vasudevan A (2013) Studies on antibiotic subsceptibility of Aeromonas hydrophila isolated from gold fish (Carassius auratus). Int J Curr Microbiol App Sci 2:7-13

Jenkins JA, Taylor PW (1995) An alternative bacteriological medium for the isolation of Aeromonas spp. J Wildl Dis 31:272-275

Jha P, Barat S, Nayak CR (2008) Fish production, water quality and bacteriological parameters of koi carp ponds under live-food and manure based management regimes. Zool Res 29:165-173

Kanchan C, Imjai P, Kanchan N, Chantabut L (2016) Antibiotic resistance of Aeromonas hydrophila isolated from diseased catfish. The 6th international conference on sciences and social sciences: mutual community engagement toward global understanding and sustainable well-being

Ko WC, Chiang SR, Lee HC, Tang HJ, Wang YY, Chunag YC (2003) In vitro and in vivo activities of fluoroquinolones against Aromonas hydrophila. Antimicrob Agents Ch 47:2217-2222

Korzekwa K, Gołaś I, Harnisz M (2012) Evaluation of anthropogenic pollution in river water based on the genetic diversity of Aeromonas hydrophila. Arch Environ Prot 38:41-50

Kozińska A, Pękala A (2010) Serotyping of Aeromonas species isolated from polish fish farms in relation to species and virulence phenotype of the bacteria. Bull Vet Inst Pulawy 54:315-320

Leung CK, Huang YW, Pancorbo OC (1992) Bacterial pathogens and indicators in catfish and pond environments. J Food Prot 55:424 427. https://doi.org/10.4315/0362-028X-55.6.424

Lin J, Blyela PT, Puckree T (2004) Antibiotic resistance profiles of environmental isolates from Nhlathuze River, KwaZulu-Natal (RSA). Water SA 30:23-28

Livrmore DM (1996) $\beta$-Lactamase in laboratory and clinical resistance. Clin Microbiol Rev 8:557-584

Lüthje P, Schwarz S (2007) Molecular basis of resistance to macrolides and lincosamides among staphylococcus and streptococci from various animal sources collected in the resistance monitoring program BfT - German vet. Int J Antimicrob Agents 29:528-535

Maalej S, Mahjoubi A, Elzari C, Dukan S (2003) Simultaneous effects of environment al factors on motile Aeromonas dynamics in an urban effluent and in the natural seawater. Water Res 37:2865-2874

Matyar F, Akken T, Vacak Y, Erslan B (2010) Aeromonas and Pseudomonas antibiotic and heavy metal resistance species from Iskenderun Bay, Turkey (Northeast Mediterranean Sea). Environ Monit Assess 167:309-320

McIntosh D, Cunningham MB, Fekete FA, Parr EM, Clark SE, Zainger ZB, Danner GR, Johnson KA, Beattie M, Ritchie R (2008) Transferable, multiple antibiotic and mercury resistance in Atlantic Canadian isolates of Aeromonas salmonicida susp. Salmonicida is associated with carriage of an IncA/C plasmid similar to the Salmonella enterica plasmid pSN254. J Antimicrob Chemother 62:1221-1228

Mudryk Z (2005) Occurrence and distribution antibiotic resistance of heterotrophic bacteria isolated from marine beach. Mar Pollut Bull 50:80-86

Mudryk Z, Skórczewski P (2007) Abundance and productivity of estuarine neustonic and planktonic bacteria. Baltic Coastal Zone 11:2540

Mudryk Z, Perliński P, Gackowska J (2015) Antibiotic resistance of Aeromonas spp. isolated from seawater and sand of marine recreation beach in the southern Baltic Sea. Baltic Coastal Zone 19:67-80

Mulyani Y, Aryantha NP, Suhandono S, Pancoro A (2018) Inestinal bacteria common carp (Carpinus carpio $\mathrm{L}$ ) as a biological control agent for Aeromonas. J Pure Appl Microbiol 12:601-610

Naylor R, Burke M (2005) Aquaculture and ocean resources. Raising tigers of the sea. Annu Res Environ Resour 30:185-218

Orozova P, Chikova VA, Kolarova V, Nenova R, Konovska M, Najdenski $\mathrm{H}$ (2008) Antibiotic resistance of potentially pathogenic Aeromonas strains. Trakia J Sci 6:71-77

Orozova P, Chikova VA, Najdenski H (2010) Antibiotic resistance of pathogenic for fish isolates of Aeromonas spp. Bulg J Agric Sci $16: 376-386$

Ozturk D, Adanir R, Turutoglu H (2007) Isolation and antibiotic susceptibility of Aeromonas hydrophila in a carp (Cyprinus carpio) hatchery farm. Bull Vet Inst Pulawy 51:361-364

Patil HJ, Benet-Perelberg A, Naor A, Smirnov M, Ofek T, Nasser A, Minz D, Cytryn E (2016) Evidence of increased antibiotic resistance in phylogenetically-diverse Aeromonas isolates from semi-intensive fish ponds treated with antibiotics. Front Microbiol 7:1875. https:// doi.org/10.3389/fmicb.2016.01875

Piotrowska M, Popowska M (2014) The prevalence of antibiotic resistance genes among Aeromonas species in aquatic environments. Ann Microbiol 64:921-934. https://doi.org/10.1007/s13213-0140911-2

Piotrowska M, Przygodzińska D, Matyjewicz K, Popowska M (2017) Occurence and variety of beta-lactamase genes among Aeromonas spp. isolated from urban wastewater treatment plant. Front Microbiol. https://doi.org/10.3389/fmicb.2017.00863

Radu S, Ahmad N, Reezal A (2003) Prevalence and resistance to antibiotics for Aeromonas spp.from retial fish Malaysia. Int J Food Microbiol 81:261-266

Ramesh S, Manivasagan S, Ashokkumar S, Rajaram G, Mayavu P (2010) Plasmid profiling and multiple antibiotic resistance of heterotrophic bacteria isolated from Muthupettai mangrove environment, southeast coast of India. Curr Res Bacteriol 3:227-237

Rashid MM, Hossian MS, Ali MF (2013) Isolation and identifiacation of Aeromonas hydrophila from silver carp and its culture environment from Mymensingh region. J Bangladesh Agril Univ 11:373-376

Reinthaler FF, Posch J, Feierl G, Wüst G, Haas D, Ruckenbauer G, Maschar F, Marth E (2003) Antibiotic resistance of E.coli in swage and sludge. Water Res 37:1685-1690 
Rhodes G, Huys J, Swings P, Megann M, Hiney P, Smith P, Pickup RW (2000) Distribution of oxytetracycline resistance plasmids between Aeromonads in hospital and aquaculture environments: implication of TN/721 in dissemination of the tetracycline resistance determinant Tet A. Appl Environ Microbiol 66:3883-3890

Rippey SR, Cabelli VJ (1989) Use of the thermotolerant Aeromonas group for the trophic state classification of freshwaters. Water Res 23:1107-1114

Roberts RJ (1993) Motile aeromonad septicaemia. In: Inglis V, Roberts RJ, Bromage NR (eds) Bacterial disease of fish. Blackwell Scientific Publication, Oxford, pp 143-156

Roberts MC (1998) Antibiotic resistance mechanisms in bacteria of oral and upper respiratory origin. Antimicrol Agen 9:255-267

Roy R, Bahadur M, Barat S (2013) Identification and antibiotic resistance of Aeromonas spp. and Salmonella spp. from the fresh water loach, Lepidocephalichthys guntea and water of terai river Lotchka, West Bengal, India. Zool Pol 58:5-17

Ryu DH, Rando RR (2001) Aminoglycoside binding to human and bacterial A-site rRNA decoding region constructs. Bioorg Med Chem Lett 9:2601-2608

Saavedra MJ, Guedes-Novais S, Alves A, Rema P, Tacão M, Correia A, Martínez-Murcia A (2004) Resistance to beta-lactam antibiotics in Aeromonas hydrophila isolated from rainbow trout (Oncorhynchus mykiss). Int Microbiol 7:207-211

Schwartz T, Kohnen W, Jansen B, Obst U (2003) Detection of antibioticresistant and their resistance genes in wastewater, surface water and drinking water biofilms. FEMS Microbiol Ecol 43:325-335

Stratev D, Daskalov H, Vashin I (2015) Characterisation and determination of antimicrobial resistance of $\beta$-haemolytic Aeromonas spp. isolated from common carp (Cyprinus carpio L.). Revue Méd Vét 166:54-61

Topić Popović N, Teskeredzić E, Strunjak-Perović I, Coz-Rakovac R (2000) Aeromonas hydrophila isolated from wild freshwater fish in Croatia. Vet Res Commun 24:371-377
Velji MI, Albright LJ (1986) Microscopic enumeration of attached marine bacteria of seawater marine sediment, fecal matter and kelp blade samples flowing pyrophosphate and ultrasound treatment. Can J Microbiol 32:121-126

Vivekanandhan G, Savithamani K, Hatha AA, Lakshmanaperumalsamy P (2002) Antibiotic resistance of Aeromonas hydrophila isolated from marketed fish and prawn of South India. Int J Food Microbiol 76:165-168

Webster FL, Thompson BC, Fulton MH, Chlestnut DE, van Dolach FR, Leight AK, Scott GI (2004) Identification of source of Escherichia coli in South Carolina estuaries uses antibiotic resistance analysis. J Exp Mar Biol Ecol 298:179-195

Wright GD (2003) Mechanisms of resistance to antibiotics. Curr Opin Chem Biol 7:563-569

Yano Y, Hamano K, Tsutsui I, Aue-Umneoy D, Ban M, Satomi M (2015) Occurrence, molecular characterization, and antimicrobial susceptibility of Aeromonas spp. in marine species of shrimps cultured at inland low salinity ponds. Food Microbiol 47:21-27

Yu JH, Han JJ, Kim HJ, Kang SG, Park SW (2010) First report of Aeromonas veronii infection in farmed Israeli carp Cyprinus carpio in Korea. J Fish Pathol 23:165-176

Yu JH, Koo BH, Kim DH, Kim DW, Park SW (2015) Aeromonas sobria infection in farmed mud loach (Misgurnus mizolepis) in Korea, a bacteriological survey. Iran J Vet Res 16:194-201

Yucel N, Aslam B, Beyatli Y (2005) Prevalence and resitance to antibiotic for Aeromonas species isolated from retial fish in Turkey. J Food Qual 28:313-324

Zdanowicz M, Mudryk Z (2017) Abundance, production and respiration of bacterioneuston and bacterioplankton in the coastal lake Dołgie Wielkie. Baltic Coastal Zone 21:73-86

Publisher's Note Springer Nature remains neutral with regard to jurisdictional claims in published maps and institutional affiliations. 